\title{
ÜLEMINEK RIIGIKEELSELE GÜMNAASIUMIÕPPELE: VILISTLASTE SEISUKOHTADE Q-METODOLOOGILINE DISKURSUSANALÜÜs
}

\author{
Anu Masso, Katrin Kello, Valeria Jakobson
}

\begin{abstract}
Ülevaade. Artikkel keskendub diskursustele, mis on seotud riigikeelsele gümnaasiumiõppele üleminekuga senistes vene õppekeelega gümnaasiumites. Empiiriliseks ülesandeks on analüüsida teiskeelse õppega seotud positsioone venekeelsete koolide vilistlaste kogemuste põhjal. Metodoloogiliseks eesmärgiks on selgitada kvantitatiivse Q-metodoloogilise analüüsi võimalusi peamiselt kvalitatiivse diskursusanalüüsi kontekstis. Uuring põhineb Q-metodoloogilistel intervjuudel, mis viidi 2010. aastal läbi neljas piirkonnas (Tallinn, Ida-Virumaa, Tartu, Läti) vene õppekeelega gümnaasiumite vilistlaste seas $(n=42)$. Selgitatakse nelja riigikeelsele õppele üleminekut iseloomustavat diskursust, mis analüüsis eristusid: "keeleliste valikuvõimaluste tähtsustamine", "rahulolu oma keeleoskuse ja integreeritusega", "vastuseis homogeniseerimisele" ning "keeleline ja kultuuriline suletus"."
\end{abstract}

Võtmesõnad: keelepoliitika, hariduspoliitika, rahvussuhted, riigikeelsele õppele üleminek, Q-metodoloogia, diskursusanalüüs, vene keel, eesti keel, läti keel

\section{Sissejuhatus}

Eesti ja Läti taasiseseisvumisjärgse keelepoliitika ühisosaks võib pidada lähtekohaks olnud etnilist koosseisu ning nõukogudeaegset venestuspoliitikat. Varasema uuringu (Siiner 2006) hinnangul on neis riikides viljeletud tugevat ja kontrollile suunatud keelepoliitikat, lähtudes normatiivsest ning kaitsvast hoiakust riigikeele suhtes. Sealhulgas kuulub olulisemate algatuste hulka seniste vene õppekeelega koolide üleminek riigikeelsele õppele. Lätis toimus üleminek veidi varem - juba 2004/05. õppeaasta alguseks pidid üldkeskhariduse asutuste õppekavad sisaldama

Artiklis analüüsitud empiirilised andmed on kogutud TÜ haridusuuringute ja õppekavaarenduse keskuse poolt läbiviidud ja Haridus- ja Teadusministeeriumilt tellitud uurimisprojekti “Vene õpilane venekeelse üldhariduskooli eestikeelses õppes" (2008-2011) raames. Artikli valmimist on toetanud ETFi grant "Meedia ja kommunikatsiooni geograafiad siirdeühiskonnas" (ETF9308) ning Euroopa Liit läbi Euroopa Regionaalarengu Fondi (Kultuuriteooria tippkeskus) ja sihtfinantseeritav teema SF0180002s07. Täname retsensente ja toimetajaid põhjalike ja asjatundlike kommentaaride eest. 
vähemalt $60 \%$ ainete õpetamist riigikeeles. Eestis on ülemineku tähtaegasid korduvalt korrigeeritud - eestikeelsele õppele ülemineku alguseks määratud 2000. aasta asendati hiljem 2007. aastaga. Õppeaasta 2011/2012 oli esimene, mil oli ette nähtud, et 10. klassi astuvad õpilased - välja arvatud spetsiifilised erandjuhud - peaksid õppima gümnaasiumiastme jooksul vähemalt 60\% minimaalsest kohustuslikust õppemahust eesti keeles (RT 2007, 61, 392).

Varasemad uuringud on näidanud (Masso, Kello 2010, 2012), et riigikeelsele õppele ülemineku õnnestumine sõltub praktilise toetuse (nt õpetajakoolituste, õppematerjalide) kvaliteedi ja kättesaadavuse kõrval oluliselt ka osapoolte (ministeeriumi ja sidusrühmade) vastastikusest mõistmisest. Eesti Haridus- ja Teadusministeerium on haridusreformi peamise ametliku eesmärgina sõnastanud vene kodukeelega noorte konkurentsivõime tõstmise nende keeleoskuse paranemise kaudu (vt nt KKK 2012). Lisaks on eestikeelsele õppele üleminekut põhjendavates sõnumites kõlanud pragmaatilisemad vajadused, nagu haridussüsteemi integreerimine ning riiklike rahaliste ressursside säästlik majandamine (nt kulutused õppematerjalidele), arvestades õpilaste arvu kahanemist. Samas, nagu osutavad mitmed uuringud (vt Masso 2010, Masso, Kello 2012), võivad erinevate ühiskonnarühmade huvid ja identiteedid olla saanud suhteliselt väiksema tähelepanu osaks.

Käesolevas artiklis keskendume riigikeelsele õppele üleminekuga seotud diskursuste ja avalike sõnumite tõlgenduste analüüsimisele erineva keelelis-kultuurilise kogemusega vilistlaste perspektiivist. Uurime, 1) millised vilistlaste keelelis-kultuurilisest kogemusest tulenevad individuaalsete positsioonide mustrid eristuvad ning 2 millised on vilistlaste tõlgendusmustreid ühendavad ja eristavad jooned. Artikli empiirilise allikana kasutame Q-metodoloogilisi intervjuusid, mis viidi läbi neljas sotsiolingvistilise keskkonna poolest eristuvas piirkonnas (Tallinn, Ida-Virumaa, Tartu, Läti).

\section{Q-metodoloogiline diskursusanalüüs}

Traditsioonilistele klassifitseerivatele analüüsimeetoditele, nagu faktor- ja klasteranalüüs, on ette heidetud võimetust selgitada hilismodernsuses toimuvaid kultuurilisi muutusi, kuna transformatsioonid avalduvad üha enam diskursustes või on nende diskursuste poolt loodud (nt van Dijk 1985, Bailey 1994, Chouliaraki, Fairclough 1999). Käesolev uuring põhineb kvalitatiivse ja kvantitatiivse lähenemise kombinatsioonil - Q-metodoloogilisel diskursusanalüüsil.

Q-metodoloogiat ${ }^{1}$ võib defineerida kui subjektiivsete positsioonide uurimist statistiliste tehnikate ja diskursiivsete mustrite leidmise abil. Rõhuasetus subjektiivsusele on peamine erinevus algset R- ehk faktoranalüusi edasi arendanud Cyril Burti ja William Stephensoni lähenemisest (vt nt Cattell 1973). Burt (1937) analüüsis indiviidide korrelatsioone nn ümberpööratud andmemaatriksi abil ja keskendus seega eelkõige uuritava nähtuse objektiivsetele parameetritele. Käesolevas uuringus on eeskujuks võetud eelkõige Stephensoni (1953), aga ka hilisem Steven Browni (1980) lähenemine, mis fokuseerus subjektiivsetele aspektidele. Subjektiivsuse analüüsi metodoloogiliseks eeliseks on suurem tähelepanu pööramine kommunikatiivsusele ja operantsusele ${ }^{2}$. Teisisõnu, subjektiivsus ehk indiviidi positsioon on enesekohane

\footnotetext{
1 Nimetame lähenemist metodoloogiaks, kuna püüame käsitleda nii klassifitseerivate meetodite tehnilisi üksikasju kui ka subjektiivsuse uurimisele omaseid protseduurilisi, teoreetilisi ja filosoofilisi põhimõtteid (vt nt Stephenson 1953). 2 Terminit operantsus oleme kasutanud ingliskeelse operant eeskujul. Termini laenas Stephenson Ameerika biheivioristilt B. F. Skinnerilt, kes kasutas mõistet viitamaks käitumisele, mis pole põhjustatud välise stiimuli poolt (vrdl eestikeelne mõiste operantne tingimine) (vt McKeown, Thomas 1988).
} 
ja edasiantav (kommunikatiivsus) ning võrreldes formaliseeritud küsitlusega sõltub vähem mõõtmisvahenditest (operantsus). Selliselt sarnaneb Q-metodoloogia kvalitatiivsele diskursuseanalüüsile. Lisaks võimalusele analüüsida subjektiivsust on käsitlused lähedased ka analüüsiprotsessi süstemaatilisuse (nt Fairclough 2003), dünaamilisuse ja konteksti rõhutamise poolest (vrd nt Wodak 1996).

Käesoleva uuringu intervjueeritavad leiti kvalitatiivse strateegilise valimi (vt nt Trost 1986) põhimõtetest lähtuvalt $(n=42)$. Strateegilisele valimile omaselt oli representatiivsuse taotluse asemel eesmärgiks diferentseerida valimit sotsiolingvistiliste kogemuste poolest ning seeläbi tagada subjektiivsete positsioonide mitmekesisus. Vilistlaste valimisse kuulusid noored, kes olid lõpetanud venekeelse gümnaasiumi aastal 2007 või 2008, mil Eestis algas sihipärane eestikeelsele õppele üleminek. Vilistlaste positsioonide mitmekesisuse tagamiseks, aga ka selgituste mõistmiseks eri kontekstides, viidi intervjuud läbi neljast sotsilingvistilise keskkonna ${ }^{3}$ poolest eristuvast piirkonnast - Tallinnast (10), Ida-Virumaalt (12), Tartust (10) ning Lätist (10) - pärit noortega. Sotsiolingvistilise keskkonna poolest on uuritav Läti rühm mõnevõrra heterogeensem (praegune elukoht Riias, hariduse omandamise koht erinev), Eesti vilistlastest eristab aga institutsionaalne kontekst (nt riigikeelse õppe korraldus). Eesmärgiks on analüüsida eri sotsiolingvistiliste kogemustega vilistlaste tõlgendusi, mitte leida eraldi diskursused valimi alarühmade lõikes. Uuritavate vilistlaste kogemused riigikeelse aineõppega gümnaasiumis olid mitmekesised, ulatudes üksikutest enamiku aineteni. Tervikvalim kujunes tegevusala lõikes suhteliselt homogeenseks (pea kõik vilistlased õppisid kõrgkoolis, erandiks kaks noort, kes käisid tööl ja/või õppisid kutsekoolis), mistõttu on tegemist spetsiifilise, õppimises pigem edukate vilistlaste valimiga. Enamik intervjueerituid omas (ning puudutas ka intervjuudes) kokkupuuteid riigikeelse õppega ka kõrgkoolis. Andmed koguti 2010. a sügisel suulise individuaalintervjuu vormis. Enamiku intervjuude kestus jäi ühe ja pooleteise tunni vahele.

Riigikeelsele õppele üleminekuga seotud subjektiivsete tõlgenduste uurimise instrumendina kasutasime nii avatud küsimusi kui ka eelnevalt sõnastud 63 väidet, mis olid valitud algse väidete koondkogumi ${ }^{4}$ ehk ligi 200 konstrueeritud väite hulgast. Koondkogum oli sõnastatud mitmekesiste allikate põhjal (nt meediatekstid, ametlikud dokumendid, akadeemilised uuringud) ning kajastas riigikeelse õppe ning keeleliste ja kultuuriliste identiteetidega seotud arusaamade mitmekesisust. Väidete mitmekesisuse tagamiseks ning arvuliseks tasakaalustamiseks valdkondade lõikes kasutasime varasemate uuringute (vt nt Masso, Kello 2010, 2012) põhjal tuletatud järgmisi analüütilisi dimensioone ja nende põhjal moodustunud 9-väljalist maatriksit (vt joonis 1): üldistusaste (riigikeelne õpe indiviidi, kooli ja klassiruumi ning ühiskonna/riigi tasandil) ning positsioonide fookus (isiklikud kogemused ja praktikad, enesekohased hoiakud ning välistele tingimustele suunatud hoiakud). Väidete konstrueerimisel jälgisime, et nimetatud sisulised valdkonnad oleksid kaetud. Väidete jaotus eri väljade vahel polnud alati üks-üheselt määratav, kuna meetodile omaselt võis üks väide sisaldada samaaegselt mitut eri aspekti.

\footnotetext{
3 Rannuti (2005) uuringu eeskujul oleme mõistnud sotsiolingvistilise keskkonna all nii suhtlusvõrgustikku makrotasandil (nt kooli eripärad) kui ka isikutevahelist suhtlusvõrgustikku mikrotasandil. Ida-Virumaa, Tartu ning Tallinna kui erinevate sotsiolingvistiliste keskkondade eristumist on näidanud varasemad kvantitatiivsed uuringud (Masso, Kello 2010).

4 Esinduslike küsitlusuuringute üldkogumi asemel eelistame väidete koondkogumi (ingl concourse) mõistet, rõhutamaks kvalitatiivuuringule omast valimi moodustamist küllastumise põhimõttel. Valimi mõiste on Q-metodoloogias tavapärasest mõnevõrra laiem - eristatakse Q-valimit (väited) ning R-valimit (indiviidid).
} 


\begin{tabular}{|c|c|c|c|}
\hline \multirow[b]{2}{*}{$\begin{array}{l}\text { Positsioonide } \\
\text { fookus }\end{array}$} & \multicolumn{3}{|c|}{ Üldistusaste } \\
\hline & $\begin{array}{l}\text { Eestikeelne õpe } \\
\text { indiviidi tasandil } \\
\text { (nt mõju valikutele, } \\
\text { võimalustele, } \\
\text { hoiakutele) }\end{array}$ & $\begin{array}{c}\text { Eestikeelne õpe } \\
\text { kooli ja klassiruumi } \\
\text { kontekstis } \\
\text { (nt toetavad tegurid, } \\
\text { probleemid ja } \\
\text { takistajad) }\end{array}$ & $\begin{array}{l}\text { Eestikeelne õpe } \\
\text { ühiskonna ja riigi } \\
\text { kontekstis }\end{array}$ \\
\hline $\begin{array}{l}\text { Isiklikud kogemused } \\
\text { ja tegevused } \\
\text { (nt kuidas olen ise } \\
\text { hakkama saanud) }\end{array}$ & $\begin{array}{l}\text { 1. Minu kogemused } \\
\text { (keeled ja } \\
\text { toimetulek) }\end{array}$ & $\begin{array}{l}\text { 2. Minu kogemused } \\
\text { (eestikeelne õpe } \\
\text { koolis) }\end{array}$ & $\begin{array}{l}\text { 3. Minu kogemused } \\
\text { (ühiskondlik sidusus } \\
\text { ja kultuur) }\end{array}$ \\
\hline $\begin{array}{l}\text { Enesekohased } \\
\text { hoiakud (nt eesti keele } \\
\text { õppimine on minu } \\
\text { meelest oluline) }\end{array}$ & $\begin{array}{l}\text { 4. Minu hoiakud (mis } \\
\text { on minu enda jaoks } \\
\text { oluline) }\end{array}$ & $\begin{array}{l}\text { 5. Minu hoiakud (mis } \\
\text { on koolis oluline) }\end{array}$ & $\begin{array}{l}\text { 6. Minu hoiakud (mis on } \\
\text { ühiskonnas oluline) }\end{array}$ \\
\hline $\begin{array}{l}\text { Välistele tingimustele } \\
\text { (nt riigi tegevusele, } \\
\text { teiste ühiskonna- } \\
\text { liikmete hoiakutele } \\
\text { ja praktikatele) } \\
\text { suunatud hoiakud }\end{array}$ & $\begin{array}{l}\text { 7. Minu hoiakud } \\
\text { (seoses } \\
\text { individuaalsete } \\
\text { valikutega) }\end{array}$ & $\begin{array}{l}\text { 8. Minu hoiakud } \\
\text { (seoses kooli } \\
\text { valikutega üldiselt) }\end{array}$ & $\begin{array}{l}\text { 9. Minu hoiakud } \\
\text { (ühiskonna ja riigi } \\
\text { valikud) }\end{array}$ \\
\hline
\end{tabular}

Joonis 1. Väidete konstrueerimise analüütiline raamistik

Konstrueeritud 63 väidet paluti uuritavatel sorteerida etteantud nõusolekuskaala $(-5 \ldots+5)$ ning fikseeritud sümmeetrilise sagedusjaotuse piires (joonis 2). Skaala koostamisel lähtusime nii soovitusest kasutada normaaljaotusele lähedase kujuga väidete ladumise vormi (Stephenson 1936) kui ka eeldusest, et huvi pakuvad eeskätt tekkivad väidete mustrid (Brown 1980). Väidete sorteerimine võimaldas vilistlastel väljendada oma subjektiivseid positsioone erinevate avalikult levinud arusaamade suhtes. Lihtsustamaks väidete ladumise protseduuri, palusime uuritavatel esmalt jagada väited 3 rühma (väited, millega nõustutakse, millega ei nõustuta või mille suhtes ollakse neutraalsel seisukohal). Alles pärast esmast sorteerimist tuli väited laduda etteantud hinnanguskaalale. Hinnangute subjektiivsus oli tagatud skaala absoluutse nullpunkti puudumise ning avatud kommentaaride lisamise võimalusega. Näiteks, kui konkreetne uuritav soovis nõustuda etteantud kvoodist suurema arvu väidetega, siis toimus skaala algse neutraalse keskpunkti mõtteline nihutamine selliselt, et kõigile etteantud väidetele leiduks skaalal koht. Kõigile uuritavatele esitati täiendavaid avatud küsimusi nende tausta (nt varasema koolikogemuse), keeleoskuse jms kohta. Samuti paluti kõigil uuritavatel kommenteerida väiteid, millele nad olid andnud äärmisi hinnanguid $(-5,-4,-3 \mathrm{ja}+3,+4,+5)$. Iga uuritava poolt väidetele antud numbrilised hinnangud fikseeris intervjueerija kirjalikult. Intervjuu helisalvestati ning salvestustest tehti sõna-sõnaline üleskirjutus. Venekeelse intervjuu jaoks konstrueeritud väited ning artikli tulemuste osas esitatud tsitaadid on tõlgitud eesti keelde. 


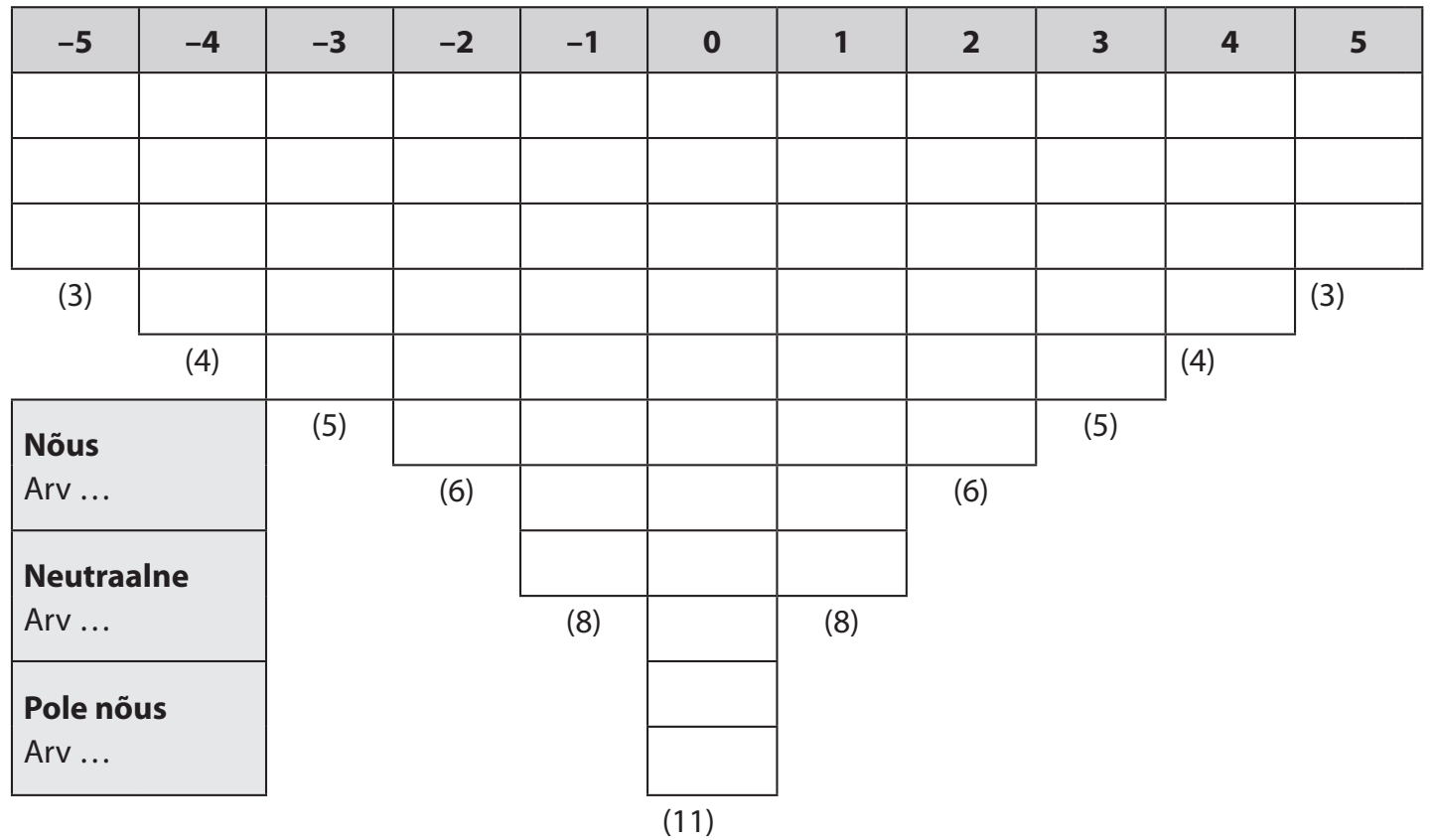

Joonis 2. Väidete sorteerimisel ette antud sagedusjaotus

Analüüsis kasutasime nii kvalitatiivseid tekstilisi andmeid kui ka väidete kvantitatiivseid hinnanguid. Intervjueeritavate poolt sorteeritud väidete analüüs keskendub kolmele statistilisele protseduurile - korrelatsioonide, faktorlaadungite ja faktorskooride arvutamisele. Esimene kasutab traditsioonilise faktoranalüüsiga sarnast arvutuskäiku, mille käigus leitakse üksikute Q-sorteerimiste vahelised seosed $^{5}$. Kuid faktortelgede pööramise asemel kasutasime subjektiivsete tõlgenduste mustrite leidmiseks faktoranalüüsi tsentroidide meetodit ehk lihtsa summeerimise meetodit ${ }^{6}$. Kuigi peakomponentide meetodit on peetud matemaatiliselt täpsemaks (Cattell 1973), eelistatakse Q-metodoloogias tsentroidide meetodit teoreetilistel kaalutlustel (Stephenson 1953) - piiramatu hulga erinevate faktorlahendite hulgast ühe struktuuri väljavalimine võimaldab arvestada uuritavate subjektiivsete tõlgendusruumidega7 ${ }^{7}$ Konstrueeritud väidetele antud hinnangute kvantitatiivne analüüs tsentroidide meetodil võimaldab esile tuua omavahel seotud väidete "taga" olevaid subjektiivseid diskursuseid või tõlgendusmustreid ${ }^{8}$. Selliselt kombineeriti analüüsis nii kvantitatiivset - subjektiivsete positsioonide mustrite leidmine faktoranalüüsi meetodi abil - kui ka kvalitatiivset lähenemist, s.t kasutatud tsentroidide meetod

\footnotetext{
5 Q-lähenemist on ekslikult peetud ka 'ümberpööratud faktoranalüüsiks', kus omaduste asemel analüüsitakse seoseid indiviidide vahel. Ümberpööratud andmemaatriks ei pruugi aga vastata korrelatsiooni ning faktoranalüüsi lineaarsuse nõuetele (vt nt Brown 1980, McKeown, Thomas 1988). Lineaarsuse nõue on Stephensoni hinnangul (1953) täidetud juhtudel, mil arvestatakse mõõtmisühikute enesekohasusega (ingl self-referent), s.t andmemaatriksi tunnused on ükshaaval koondatud psühholoogilise olulisuse keskväärtuse ümber.

6 Kuigi ka tsentroidide meetodil põhineva faktoranalüüsi korral kasutatakse faktorite arvu määramisel statistilisi kriteeriume (nt Kaiseri omaväärtuste ja Catelli joondiagrammi meetodid) (vt Hill, Lewicki 2006), on olulisemad siiski teoreetilised kaalutlused.

7 Tsentroide võib mõista kui keskväärtust, mis iseloomustab seoseid kõikide ladumiste vahel, s.t tsentroid esindab vektorit, mis ulatub kõige kaugema dimensioonini mitmemõõtmelises andmeruumis (vt nt Child 2006).

8 Algselt nimetati Q-metodoloogias (Stephenson 1953, Brown 1980) analüüsi tulemusi faktoriteks. Hiljem on lähenemist kombineeritud kvalitatiivse diskursusanalüüsi põhimõtetega (vt nt Dryzek 2004) või on kvalitatiivse lähenemise eeskujul väidete koondkogumit nimetatud avalikuks diskursuseks ning leitavaid faktoreid individuaalseteks diskursusteks (vt nt Aalto 2003). Sellist rõhuasetuse muutust Q-metodoloogias on nimetatud nihkeks konstruktivismist (nt Stephensoni keskendumine uuritavate enesekohastele positsioonidele) konstruktsionismile (domineerivate sotsiaalsete tõlgenduste määratlemine konkreetses valdkonnas) (Watts, Stenner 2012: 42).
} 
võimaldas uurijatel lisaks statistilistele kriteeriumitele arvestada kvalitatiivsete andmetega üksikute individuaalsete positsioonide omavahelisel võrdlemisel.

Käesolev analüüs on tehtud PQMethod tarkvara abil ning faktorstruktuuri valik on tehtud faktorite paaritise võrdleva pööramise teel. Lisaks faktorlaadungitele ${ }^{9}$, mis võimaldavad määratleda intervjueeritavate jaotumist diskursuste vahel, arvutatakse järgnevas analüüsis ka faktorskoorid ${ }^{10}$, mis võimaldavad iseloomustada faktori koosseisu määravaid väiteid skaala algsetes väärtustes ${ }^{11}$. Lisaks on artiklis kvalitatiivselt analüüsitud väidetele vabas vormis antud kommentaare ning vastuseid avatud küsimustele. Tekstiliste andmete analüüsimisel kasutasime tarkvara Maxqda. Kvalitatiivse analüüsi käigus keskendusime ühe alateema või väite tähendusliku mitmekesisuse uurimisele ning subjektiivsete positsioonide rühmade erinevuste ja sarnasuste selgitamisele.

\section{Tulemused}

Järgnevalt selgitame vilistlaste subjektiivsete positsioonide diskursuseid nii kvantitatiivselt -diskursuseid statistiliselt oluliselt eristavate väidete faktorskooride abil kui ka kvalitatiivselt, toetudes intervjueeritavate poolt lisatud kommentaaridele.

Tabelis 1 on esitatud uuringus osalejate seotus iga leitud diskursusega kvantitatiivselt. Indiviidi seotust diskursusega näitab faktorlaadung - mida suurem see on, seda tugevamalt on indiviid diskursusega seotud. Mõne indiviidi arvamusi iseloomustab samaaegselt mitu diskursust (kõrge faktorlaadung mitmes faktoris, tabelis märgitud kursiivis). Kahe uuritava faktorkuuluvus on küll määratletav (kõrgeim faktorlaadung "keeleliste valikuvõimaluste tähtsustamise" faktoris), kuid pole hinnangute põhjal selgelt eristuv (statistiliselt madalad faktorlaadungid).

Järgnevates, diskursuste sisu analüüsivates tabelites (2-5) on esitatud ainult need väited, millele antud hinnangud eristasid diskursust statistiliselt oluliselt (kokku 36). Väljajäetud väidetest osa puudutas küsimusi, mille suhtes vilistlastel puudusid selged seisukohad (nt kutseharidus, põhikoolist väljalangemine (väide 35); elus vedamine võrreldes eakaaslastega (2); eestikeelsele õppele üleminekuga seotud võltsparaadlikkus (50)). Teiste väljajäetud väidete osas olid hinnangud kas suhteliselt üksmeelselt pigem nõustuvad (nt vene keele suuremale kasutusmugavusele osutamine (väide 12) või mure oma vene keele oskuse (33), etnilise identiteedi (46) ja keelelise diskrimineerimise pärast (56)) või pigem mitte-nõustuvad (nt rahvustevaheliste suhete paranemise küsimus (19), eesti ja inglise keele õppimise keerukuse võrdlus (54)).

9 Faktorlaadungid on väärtused, mis väljendavad iga ladumise seoseid tsentroidiga ehk vektorite keskmisega.

10 Arvutuslikult on faktorskooride (ingl factor array) korral tegemist faktorlaadungite kaalude summaga ridade lõikes, mis on omistatud igale analüüsiühikule indiviidi poolt, kes esindab antud faktorit: $w=\frac{f}{1-f^{e}}$, kus $f$ on faktorlaadung ning $w$ on iga uuritava kaal (vt nt Spearman 1927). Faktorskoorid arvutatakse standardiseerituna (z-skooridena), kuid võimaldamaks võrdluseid eri diskursuste vahel, konverteeritakse täisarvudesse $(-5 \ldots+5)$. Faktorskoore ei tule mõista mitte üksnes teatud ideaalse sorteerimisena (vt nt Aalto 2003: 81), vaid leiame, et need võimaldavad sisuliselt välja tuua ka erinevusi/sarnasusi ühe diskursuse sees ja mitme diskursuse vahel. Kuigi mitmetes uuringutes (vt nt Snelling 1999) on soovitatud keskenduda tõlgendustes eelkõige faktorskooride äärmuslikele väärtustele (nt +5, +4 ning -5 ja -4), on käesolevas uuringus arvestatud kõigi statistiliselt oluliselt eristuvate väidetega.

11 Erinevalt Burti (1937) kasutatud indiviidide korrelatsioonide analüüsist keskendutakse käesolevalt Stephensoni (1953) eeskujul nii indiviidide kui ka uurimisinstrumendina kasutatud väidete samaaegsele analüüsile. Stephensoni Q-metodoloogia põhimõtteid on varemalt enam kasutatud poliitilise kommunikatsiooni (nt Aalto 2003) ja kommunikatsiooniteooria valdkondades (nt Grosswiler 1990). Vähem on lähenemist kasutatud meedia ja kommunikatsiooni (nt Singer 1998/1999) ning keelelise kommunikatsiooni uuringutes (nt Barchak, Marshall 1999). 
Tabel 1. Faktorlaadungid eristuvate diskursuste ja uuritavate lõikes*

\begin{tabular}{|c|c|c|c|c|c|}
\hline \multirow[b]{2}{*}{ Sugu } & \multirow[b]{2}{*}{ Piirkond } & \multicolumn{4}{|c|}{ Diskursus } \\
\hline & & $\begin{array}{c}\text { Vastuseis } \\
\text { homogeni- } \\
\text { seerimisele }\end{array}$ & $\begin{array}{c}\text { Rahulolu oma } \\
\text { keeleoskuse ja } \\
\text { integreeritusega }\end{array}$ & $\begin{array}{l}\text { Keeleliste valiku- } \\
\text { võimaluste } \\
\text { tähtsustamine }\end{array}$ & $\begin{array}{c}\text { Keeleline ja } \\
\text { kultuuriline } \\
\text { suletus }\end{array}$ \\
\hline $\mathrm{N}$ & Eesti, Ida-Viru & 0.536 & 0.051 & 0.487 & 0.131 \\
\hline$M$ & Eesti, Tallinn & 0.531 & 0.247 & 0.343 & -0.321 \\
\hline $\mathrm{N}$ & Eesti, Tartu & 0.404 & 0.026 & 0.191 & 0.078 \\
\hline $\mathrm{N}$ & Eesti, Tartu & 0.382 & 0.296 & 0.300 & 0.012 \\
\hline $\mathrm{N}$ & Läti & 0.018 & 0.837 & 0.088 & 0.012 \\
\hline $\mathrm{N}$ & Eesti, Tartu & -0.019 & 0.766 & -0.029 & 0.098 \\
\hline $\mathrm{N}$ & Eesti, Tartu & 0.227 & 0.765 & -0.053 & -0.021 \\
\hline $\mathrm{N}$ & Eesti, Tartu & 0.139 & 0.691 & 0.248 & -0.071 \\
\hline $\mathrm{N}$ & Eesti, Ida-Viru & 0.203 & 0.688 & 0.129 & 0.015 \\
\hline$M$ & Läti & 0.014 & 0.639 & 0.170 & -0.077 \\
\hline$M$ & Läti & 0.148 & 0.631 & 0.084 & 0.235 \\
\hline $\mathrm{N}$ & Eesti, Ida-Viru & -0.097 & 0.611 & 0.127 & 0.154 \\
\hline $\mathrm{N}$ & Läti & 0.115 & 0.609 & 0.232 & -0.146 \\
\hline$M$ & Läti & 0.144 & 0.568 & 0.163 & 0.072 \\
\hline $\mathrm{N}$ & Läti & 0.087 & 0.500 & 0.430 & -0.077 \\
\hline $\mathrm{M}$ & Eesti, Ida-Viru & -0.102 & 0.488 & 0.375 & -0.036 \\
\hline$M$ & Eesti, Tallinn & 0.184 & 0.424 & 0.252 & 0.148 \\
\hline$M$ & Läti & 0.032 & 0.157 & 0.683 & -0.019 \\
\hline$M$ & Eesti, Ida-Viru & -0.037 & 0.255 & 0.682 & -0.108 \\
\hline $\mathrm{N}$ & Eesti, Tartu & 0.081 & 0.167 & 0.618 & 0.018 \\
\hline $\mathrm{N}$ & Eesti, Tartu & 0.218 & 0.333 & 0.608 & 0.154 \\
\hline$M$ & Eesti, Ida-Viru & -0.031 & 0.200 & 0.588 & -0.136 \\
\hline$M$ & Eesti, Ida-Viru & -0.034 & 0.343 & 0.587 & -0.106 \\
\hline $\mathrm{N}$ & Eesti, Ida-Viru & -0.015 & 0.230 & 0.584 & -0.107 \\
\hline $\mathrm{N}$ & Eesti, Tallinn & -0.020 & 0.305 & 0.581 & 0.120 \\
\hline$M$ & Eesti, Ida-Viru & 0.038 & 0.408 & 0.561 & 0.100 \\
\hline$M$ & Eesti, Tartu & 0.105 & 0.294 & 0.530 & 0.107 \\
\hline $\mathrm{M}$ & Eesti, Tallinn & 0.001 & 0.488 & 0.527 & 0.155 \\
\hline $\mathrm{N}$ & Eesti, Tartu & -0.001 & 0.104 & 0.523 & 0.296 \\
\hline $\mathrm{N}$ & Eesti, Tallinn & 0.089 & 0.262 & 0.480 & -0.194 \\
\hline $\mathrm{N}$ & Läti & 0.416 & 0.076 & 0.476 & 0.009 \\
\hline $\mathrm{N}$ & Läti & 0.405 & 0.109 & 0.469 & 0.041 \\
\hline $\mathrm{N}$ & Eesti, Ida-Viru & 0.209 & -0.220 & 0.469 & -0.034 \\
\hline $\mathrm{N}$ & Eesti, Tartu & 0.386 & -0.420 & 0.443 & -0.122 \\
\hline $\mathrm{N}$ & Läti & 0.376 & 0.246 & 0.440 & 0.235 \\
\hline $\mathrm{N}$ & Eesti, Tallinn & 0.139 & 0.394 & 0.383 & 0.186 \\
\hline $\mathrm{N}$ & Eesti, Ida-Viru & -0.225 & 0.226 & 0.376 & 0.015 \\
\hline $\mathrm{N}$ & Eesti, Tallinn & 0.006 & 0.096 & 0.337 & -0.143 \\
\hline$M$ & Eesti, Tallinn & 0.164 & 0.203 & 0.298 & 0.131 \\
\hline $\mathrm{N}$ & Eesti, Tallinn & -0.020 & 0.043 & 0.267 & 0.153 \\
\hline $\mathrm{N}$ & Eesti, Tallinn & 0.120 & -0.134 & 0.204 & 0.462 \\
\hline$M$ & Eesti, Ida-Viru & 0.177 & 0.346 & 0.306 & -0.439 \\
\hline
\end{tabular}

* Statistiliselt olulised faktorlaadungid on märgitud tumedas kirjas (antud juhul faktorlaadungid, mis ületavad väärtuse $0,325[p>0.01])$. Mitmes diskursuses statistiliselt olulised faktorlaadungid on märgitud kursiivis. 
Lisaks väidetele antud hinnangute ja indiviidide faktorkuuluvuse kvantitatiivsele analüüsile tsiteerime diskursust iseloomustavaid kommentaare, mida uuritavad vabas vormis lisasid. Tsitaatides on nurksulgudes märgitud kommenteeritud väite number. Samuti on iga tsitaadi juures märgitud uuritava sotsiolingvistiline kuuluvus.

\subsection{Keeleliste valikuvõimaluste tähtsustamine}

See diskursus on uuritavate poolest kõige arvukam, selle defineerimises osales 21 intervjueeritut (vt tabel 1). Ühtlasi iseloomustab diskursust regionaalne mitmekesisus - intervjueeritavad olid võrreldaval määral pärit Ida-Virumaalt (7), Tallinnast (5), Tartust (5) ning Lätist (4). Tabelis 2 on esitatud diskursust eristavate väidete standardiseeritud faktorskoorid.

Tabel 2. Diskursust "keeleliste valikuvõimaluste tähtsustamine" eristavad väited*

\begin{tabular}{|c|l|c|}
\hline Väite $\mathbf{n r}$ & \multicolumn{1}{|c|}{ Väide } & Faktorskoor \\
\hline 59 & $\begin{array}{l}\text { Paljud probleemid oleksid lahendatud, kui Eestis (Lätis)' hakkaks olema } \\
\text { kaks riigikeelt - eesti (läti) ja vene keel }\end{array}$ & 5 \\
\hline 61 & Minu arust on inglise keel venelastele palju vajalikum kui eesti (läti) keel & 2 \\
\hline 52 & $\begin{array}{l}\text { Ma arvan, et kui minust saab mingi valdkonna väga hea spetsialist, siis } \\
\text { jõuan elus edasi ka ilma eesti (läti) keeleta }\end{array}$ & 1 \\
\hline 63 & $\begin{array}{l}\text { Peaks olema nii, et kui soovid, võid valida 60\% aineid eesti (läti) keeles, aga } \\
\text { kui ei soovi, võid jätkata õppimist emakeeles }\end{array}$ & $\begin{array}{l}\text { Tänu sellele, et valdan nii vene kui ka eesti (läti) keelt, on mul rohkem } \\
\text { võimalusi saavutada edu kui nendel minu eakaaslastel (eestlastel (lätlastel) } \\
\text { või venelastel), kes valdavad ainult üht keelt }\end{array}$ \\
\hline 7 & $\begin{array}{l}\text { Eesti (läti) keele õppimisel aitas mind väga eesti (läti) meedia kasutamine } \\
\text { ning võimalus kasutada eesti (läti) keelt erinevates olmesituatsioonides }\end{array}$ & 1 \\
\hline 58 & $\begin{array}{l}\text { Nendes ainetes, mida õppisin koolis eesti (läti) keeles, pühendati liiga palju } \\
\text { tähelepanu keelele ja liiga vähe ainele }\end{array}$ & -2 \\
\hline
\end{tabular}

* Tabelites 2-5 on esitatud vaid statistiliselt oluliselt eristuvad väited olulisusenivool $p \leq .05$.

Eristuvate väidete analüüs näitab, et selle diskursuse eripäraks on keeleliste valikuvõimaluste tähtsustamine. Viimane väljendub eelkõige nõusolekus kahe riigikeele - eesti/läti ja vene - vajalikkuse väitega (59) ning väitega inglise keele suuremast instrumentaalsest kasulikkusest võrreldes riigikeelega (61). Kahe riigikeele kasulikkusega nõustunud intervjueeritavate hinnangul oleks kahe riigikeele kehtestamine õiglane ning võimaldaks tagada rahvuste võrdsuse hariduses ja töösfääris, aga muudaks vähem tähtsaks ka ülemineku riigikeelsele aineõppele. Seejuures ei eitatud praeguse riigikeele oskamise tähtsust, nagu näites (1).

(1) [59] --- Ma arvan, et jah, paljud probleemid oleksid lahendatud --- needsamad reformid. Ma arvan, et võiks kuidagi --- sellele mitte tähelepanu pöörata. --- paljudes riikides on kaks riigikeelt, isegi rohkem, kolm - kus vähemuste protsentuaalne osakaal on palju väiksem kui meil Eestis. Nii et ma arvan, et see küsimus on väga aktuaalne. Kaks riigikeelt --- lahendaks

12 Läti vilistlastele esitatud väidetes olid Eestile või eesti keelele osutavad sõnad asendatud Lätile või läti keelele osutavatega. 
väga palju mingeid selliseid probleeme, arusaamatuid olukordi. --- Kõikjal on muidugi vaja eesti keele oskust ---. (Narva)

Ühe noore hinnangul vähendanuks kaks riigikeelt eestlaste ja venelaste vahelisi pingeid - kuid samas ta möönis, et üks riigikeel võib olla mõistetav riikliku ühtekuuluvustunde tagajana (näide 2).

(2) [59] --- probleemid oleksid tõepoolest lahendatud, vähemalt ei oleks võibolla sellist otse konfrontatsiooni ses mõttes, et venelased ja eestlased. Aga sellisel juhul peab venelaste poolt olema mõistmine, et nad elavad Eestis, see on eraldi riik, oma poliitika, oma väärtuste, oma kultuuriga. Ja mida ma väga sageli täheldan venelaste poolt, [on] selline suhtumine, et pidevalt surutakse Venemaa poole. Venelased peavad mõistma, et nii ei tule teha. Riik ja eestlased võiksid ise valida, mida nad tahavad teha ja mida nad tahavad, et riigis oleks. See tähendab, [see on] võib-olla peamine probleem, miks praegu ei saa lubada seda, et riigis on kaks riigikeelt. (Tartu)

Kui riiklikest valikutest rääkides toodi ühtviisi välja nii instrumentaalseid kui ka integratiivseid argumente, siis riiklike valikute seostamisel omaenese keeleliste väärtustega oli fookus pigem instrumentaalne (näited 3 ja 4).

(3) [61] --- Ma arvan, et inimene peab ise valima [kas tema jaoks on tähtsam inglise või eesti keel]. Ma arvan, mis minusse puutub, siis antud hetkel on eesti keel tähtsam kui inglise. Kuna ma töötan, tööl on vaja eesti keelt, ja ma elan siin. (Narva)

(4) [61] --- Igal juhul, kui inimene tegeleb tõsise asjaga, siis tal on vaja inglise keele oskust, ilma selleta ei sõida sa kuskile. Jällegi, kõige tavalisem infootsing Internetis --- (Tallinn)

Ühtlasi oli sellele diskursusele iseloomulik kriitilisus kooli riigikeelsele aineõppele ülemineku suhtes, rõhutades õpilaste valikuvõimaluse tähtsust (väide 44). Samas ei nõustutud ohuga, et riigikeelses õppes pööratakse liiga suurt tähelepanu keelele ja liiga väikest ainele (väide 58). Mittenõustumine selle väitega oli osal juhtudel seotud vähese riigikeelse aineõppe kogemusega koolis ja ülikoolis (st väide vastajat otseselt ei puudutanud), osal juhtudel aga ei nõustutud väite endaga. Seega oli vilistlaste argumentatsioonide rõhuasetus siin pigem õpilaste keelelis-kultuurilistel valikuvõimalustel, mitte aga konkreetsetel teiskeelse aineõppe metoodikaga seotud valikutel, nagu näites (5).

(5) [44] Ma leian, et muidugi peab valik jääma õpilase teha. Kui ta tahab, et need ained oleksid, et neid õpetataks eesti keeles, siis las ta väljendab oma soovi, et ma tahan, ja las siis õpib. - Aga kui tal ei ole soovi? - Siis las jätkab õppimist emakeeles, vene keeles. (Narva)

Väitega 44 nõustumine on selles diskursuses sarnane allpool peatükis 3.3 esitatud diskursusega "vastuseis homogeniseerimisele". See-eest erinevalt "keelelise ja kultuurilise suletuse" diskursusest, kus väljendati muuhulgas vähest valmidust kasutada formaalharidussüsteemiväliseid võimalusi riigikeele õppimisel (nt meedia, olmelised kontaktid), ilmnes selles diskursuses ka vastavate alternatiivide nägemine riigikeele õppimisel. 


\subsection{Rahulolu oma keeleoskuse ja integreeritusega}

See diskursus on seda defineerivate vilistlaste arvu poolest teisel kohal (13 uuritavat). Diskursuse koosseisus on ülekaalus Läti noored (6), kuid esindatud on ka Tartu (3), Ida-Viru (3) ja Tallinna (1) vilistlased.

Tabel 3. Diskursust "rahulolu oma keeleoskuse ja integreeritusega" eristavad väited

\begin{tabular}{|c|c|c|}
\hline Väite nr & Väide & Faktorskoor \\
\hline 55 & $\begin{array}{l}\text { Tänu eesti (läti) keele oskusele tunnen, et olen Eesti (Läti) ühiskonda integree- } \\
\text { ritud paremini kui need minu eakaaslased, kes oskavad keelt halvasti }\end{array}$ & 5 \\
\hline 28 & Olen rõõmus, et sain koolis mitte-emakeeles õppimise kogemuse & 4 \\
\hline 10 & $\begin{array}{l}\text { Tänu eesti (läti) keele oskusele avaneb noortel võimalus osaleda aktiivselt } \\
\text { ühis(konna)elus }\end{array}$ & 4 \\
\hline 53 & $\begin{array}{l}\text { Eesti (läti) keele omandamise seisukohalt eestikeelne (lätikeelne) aineõpe } \\
\text { täiiendas keeletunde }\end{array}$ & 3 \\
\hline 13 & Eesti (läti) keele oskus on minu jaoks väga tähtis & 2 \\
\hline 48 & $\begin{array}{l}\text { Nende ainete eestikeelne (lätikeelne) õpetamine, mida õppisin omal ajal } \\
\text { koolis eesti (läti) keeles, oli täiesti põhjendatud }\end{array}$ & 2 \\
\hline 30 & $\begin{array}{l}\text { Üleminek eesti (läti) õppekeelele gümnaasiumis ei olnud minu jaoks nii } \\
\text { keeruline, kuna mind toetas perekond ja head õpetajad }\end{array}$ & 2 \\
\hline 36 & $\begin{array}{l}\text { Õpilase enda huvi ja pere toetus on tähtsamad kui varustatud klassiruum ja } \\
\text { hea õpetaja }\end{array}$ & 0 \\
\hline 14 & $\begin{array}{l}\text { Eestikeelsele (lätikeelsele) õppele ülemineku tulemusel vähenevad pinged } \\
\text { eestlaste (lätlaste) ja venelaste vahel }\end{array}$ & 0 \\
\hline 59 & $\begin{array}{l}\text { Paljud probleemid oleksid lahendatud, kui Eestis (Lätis) hakkaks olema kaks } \\
\text { riigikeelt - eesti (läti) ja vene keel }\end{array}$ & 0 \\
\hline 51 & $\begin{array}{l}\text { Üleminek eestikeelsele (lätikeelsele) õppele võib olla vajalik, kuid mitte } \\
\text { sellise kava alusel ja sellisel viisil, nagu seda tehakse praegu }\end{array}$ & -1 \\
\hline 3 & Paljudel ei lähe eesti (läti) keelt pärast kooli enam tarvis & -2 \\
\hline 60 & $\begin{array}{l}\text { Eestikeelsele (lätikeelsele) õppele ülemineku sunniviisilisus ei too kellelegi } \\
\text { head, vaid pigem tekitab pingeid ja vastuseisu noorte seas }\end{array}$ & -3 \\
\hline 58 & $\begin{array}{l}\text { Nendes ainetes, mida õppisin koolis eesti (läti) keeles, pühendati liiga palju } \\
\text { tähelepanu keelele ja liiga vähe ainele }\end{array}$ & -3 \\
\hline 9 & $\begin{array}{l}\text { Väide, et ainete õpetamine eesti (läti) keeles tõstab õpilaste } \\
\text { konkurentsivõimet, on absurdne }\end{array}$ & -4 \\
\hline 37 & $\begin{array}{l}\text { Eesti (läti) keele sildi all pööratakse vene lapsi eesti (läti) usku - vene } \\
\text { mentaliteedi asemel sunnitakse neile peale eesti (läti) oma }\end{array}$ & -5 \\
\hline
\end{tabular}

Tabelis 3 esitatud diskursust eristavate väidete faktorskooridest ilmneb, et diskursuse iseloomulikuks jooneks on avalike/riiklike keelepoliitiliste rõhuasetustega nõustumine. Argumentatsioonides tuginetakse isiklikele positiivsetele kogemustele. Näiteks nõustusid seda diskursust defineerivad vilistlased riigikeele tähtsusega nii üldiselt (nähes riigikeele oskuses koostegemise ja osalemise võimaldajat, näide 6) kui ka iseendasse puutuvalt (öeldes, et riigikeele oskus on toetanud nende integreerumist ühiskonda, näide 7).

(6) [10] Ma olen täiesti nõus sellega, et nad saavad võtta osa mingitest üritustest, mis on ainult eesti keeles --- st suhelda inimestega, mitte ainult oma ringkonnaga, ütleme maailma tundma õppida. (Tartu) 
(7) [55] Jah, ma olen rohkem integreeritud eesti ühiskonda, kuna ma suhtlen valdavalt eestlastega. Need minu sõbrad, kes räägivad eesti keelt halvasti, justkui oskavad seda gümnaasiumi tasemel, või ütleme, selle kursuse [tasemel], millel nad õpivad, nad tulevad töödega suurepäraselt toime, kuid neil ei ole suhtlemist, ning sellest tulenevalt on neil raske ületada suhtlusbarjääri. Ja seetõttu nad ei ole eesti ühiskonda nii hästi integreeritud. Eestikeelne õpe [ülikoolis], see ei tähenda, et me oleme juba Eesti ühiskonnas. (Kiviõli)

Ühtlasi nõustusid seda diskursust defineerivad noored riigikeeleoskuse positiivsete instrumentaalsete mõjudega individuaalse elutee, s.t kas ametialase või muu kasutusvajaduse seisukohalt (mittenõustumine väitega 3). Sarnaselt teiste diskursustega seostati keeleoskuse tähtsust ka siin indiviidi tulevase elukohamaaga (näide 8).

(8) [3] --- Praegu sõidavad inimesed väga sageli välismaale. --- Mul väga paljud minu sõbrad, klassikaaslased on sõitnud õppima välismaale, peamiselt Inglismaale. Ja no seal nagu väga ei ole läti keelt tarvis, kuigi niipalju kui ma tean, nad loevad sedasama Delfit, et olla kogu aeg kursis. (Läti)

Teine sellele diskursusele iseloomulik joon on positiivsete kogemuste rõhutamine seoses riigikeeles óppimisega koolis. Rahulolu väljendati nii üldiselt (nõustumine väitega 28) kui ka konkreetsemalt seoses riigikeelsele õppele üleminekuga (vastavalt nõustumine väitega 53 ja mittenõustumine väidetega 9, 51). Üldist rahulolu toetas nii vastanute koolikogemus tasakaalustatud keele- ja aineõppega (näide 9; mittenõustumine väitega 58) kui ka usk kultuuriliste eripärade arvestamisse teiskeelses õppes (näide 10; mittenõustumine väitega 37).

(9) [58] See on täielik lollus. Õpetajad, kes neid aineid õpetavad, ja need, kes kogu selle süsteemi, ütleme, välja mõtlevad, mulle tundub, paigutavad keeleõppe ja, ütleme, aineõppe, võrdsetele positsioonidele. Seal ei ole sellist ülekaalu, et kas rohkem tähelepanu läheb keelele või ainele. Seda õpitakse kõike koos, mulle tundub. (Tallinn)

(10) [37] Siin ma kindlasti ei ole nõus. Pööratakse eesti usku... Mis mentaliteet on inimesel... ma ei saa sulle öelda... Siiski esimesed seitse aastat... ta kasvab ju vene perekonnas. Ja see mentaliteet on tal seitsme aastaga juba välja kujunenud. --- (Kiviõli)

Positiivset suhtumist seoses riigikeelse õppega soosis nii koduse kui ka õpetajapoolse toe olemasolu (vt väide 30); vabas vormis lisatud kommentaarides rõhutati aga eelkõige õpetajatepoolse toetuse tähtsust, kuna erinevalt perekonnast omatakse õppetöö läbiviimiseks vajalikke metodoloogilisi teadmisi (näide 11).

(11) [30] Sellega ma võin nõustuda. Jah, tõepoolest, õpetajad aitasid. Aitasid sellega, et nad ei esinenud, et vat, peab olema $80 \%$ läti keeles. Minutite mõõtmist, seda ei olnud. Õpetajad ju, nad mõistavad, mõistavad siiski õpilaste huve. Ja formaalselt nad ei lähenenud sellele küsimusele, nagu näiteks ametnikud, kes selle kõik välja mõtlesid. Meil on õpetajad efektiivsemad, muidugi, kuigi neil ei ole metodoloogiat, nagu tavaliselt, aga [neil] on pea, nad teavad, mida teha. Just seetõttu üleminek ei olnud, noh, nii raske, nagu oleks võinud olla. No aga see, et perekond --- perekonnal ei 
ole sellist funktsiooni - aidata õppes, eriti, kui [õpilane on] juba piisavalt suur - 8., 9., 10. klass. --- Pere on muu, mitte õppimise jaoks. (Läti)

Seda diskursust võib pidada üheks paremini eristuvaks, kuna teiste diskursustega kattuvaid ja statistiliselt oluliselt eristuvaid väiteid on vaid üks (55): sarnaselt diskursusega "vastuseis homogeniseerimisele", nõustuti ka siin (kuid veelgi tugevamalt) väitega, et tänu riigikeele oskusele ollakse ühiskonda paremini integreeritud kui keelt mitteoskavad eakaaslased. Kahte diskursust eristab väite 55 osas riikliku integratsioonipõhimõtte tõlgendus - kui selles diskursuses on keeleoskus ja rahulolu isikliku kooli- ja elukogemusega viinud integreeritusetundeni, siis diskursuses "vastuseis homogeniseerimisele" väljendati pigem vastupanu põhimõtte "keel kui integratsiooni eeltingimus" suhtes.

\subsection{Vastuseis homogeniseerimisele}

Selle diskursuse defineerimises osalenute hulk on kahe eelneva diskursusega võrreldes tagasihoidlikum (4), kuid samas on selles esindatud kõik kolm Eesti sotsiolingvistilist piirkonda (kaks esindajat Tartust, üks Tallinnast, üks Ida-Virumaalt).

Tabel 4. Diskursust "vastuseis homogeniseerimisele" eristavad väited

\begin{tabular}{|c|c|c|}
\hline Väite nr & Väide & Faktorskoor \\
\hline 18 & $\begin{array}{l}\text { On raske mõista, mida halba oli praeguses Eesti (Läti) haridussüsteemis, kus } \\
\text { külg külje kõrval on olemas nii eesti (läti) kui ka vene õppekeelega koolid }\end{array}$ & 5 \\
\hline 44 & $\begin{array}{l}\text { Peaks olema nii, et kui soovid, võid valida } 60 \% \text { aineid eesti (läti) keeles, aga } \\
\text { kui ei soovi, võid jätkata õppimist emakeeles }\end{array}$ & 4 \\
\hline 55 & $\begin{array}{l}\text { Tänu eesti (läti) keele oskusele tunnen, et olen Eesti (Läti) ühiskonda } \\
\text { integreeritud paremini kui need minu eakaaslased, kes oskavad keelt } \\
\text { halvasti }\end{array}$ & 2 \\
\hline 6 & $\begin{array}{l}\text { Eestikeelse (lätikeelse) ainete õppimise tagajärjel minu aineteadmised } \\
\text { kannatasid }\end{array}$ & 0 \\
\hline 1 & Kui inimene elab Eestis (Lätis), peab ta oskama eesti (läti) keelt & 0 \\
\hline 29 & $\begin{array}{l}\text { Igapäevaelus ei ole mul läinud tarvis seda sõnavara, mille omandasin } \\
\text { koolis, õppides aineid eesti (läti) keeles }\end{array}$ & 0 \\
\hline 52 & $\begin{array}{l}\text { Ma arvan, et kui minust saab mingi valdkonna väga hea spetsialist, siis } \\
\text { jõuan elus edasi ka ilma eesti (läti) keeleta }\end{array}$ & -1 \\
\hline 26 & $\begin{array}{l}\text { Koolis ma kartsin eestikeelset (lätikeelset) aineõpet ja minu hirm osutus } \\
\text { põhjendatuks }\end{array}$ & -1 \\
\hline 31 & $\begin{array}{l}\text { Kõige tähtsam on see, et aine oleks huvitav - kui aine ja teema on } \\
\text { huvitavad, muutub õppekeel teisejärguliseks }\end{array}$ & -3 \\
\hline 20 & $\begin{array}{l}\text { Koolis ma alguses natuke kartsin õppida aineid eesti (läti) keeles, kuid minu } \\
\text { hirm osutus põhjendamatuks }\end{array}$ & -4 \\
\hline
\end{tabular}

Seda diskursust eristab teistest fokuseeritum kriitilisus haridussüsteemis toimuva ehk eestikeelsele aineõppele ülemineku suhtes. Kriitikat riigikeelse aineõpetuse suhtes argumenteeriti näiteks asjaoluga, et teises keeles aine õppimine võib veelgi vähendada õpilaste niigi tagasihoidlikku õpimotivatsiooni (näide 12). Rõhutati õpilaste passiivsust õppeprotsessis tervikuna ning seeläbi suurema 
interaktiivsuse vajadust eestikeelses aineõppes. Viimasest tulenevalt pooldasid sellesse diskursusse kuuluvad Eesti vilistlased suhteliselt üksmeelselt olemasoleva koolisüsteemi säilimist (näide 13).

(12) [31] No lastel pole nii võimalik, et kõik lihtsalt on huvitav, et nad ise kuidagi kõike õpiksid, kõike teaksid, ei ole midagi sellist. Mitte keegi ei õpi, mitte keegi ei taha õppida, kõik kirjutavad maha, ja üldse. (Tartu)

(13) [18] No jah, raske mõista, miks nad lihtsalt ei jäta seda küsimust rahule, ja las olla nagu viis aastat tagasi, venelased vene koolis, eestlased eesti omades. Need, kes tahavad minna õppima eesti keeles, tee on lahti, kui on selline soov. Ei oleks sellist probleemi, et vene õpetajad peavad koolist lahkuma. Oleks neil jälle nii koht kui ka töö. (Narva)

Skeptilisus eestikeelse aineõpetuse suhtes on sellele diskursusele omane vaatamata diskursust defineerivate vilistlaste suhteliselt kõrgele hinnangule oma riigikeeleoskuse suhtes. Tänu oma riigikeele oskusele peeti omaenda ühiskondlikku integreeritust suhteliselt heaks (väite 55 faktorskoor 2). Siiski väärtustati riigikeele oskuse asemel kõrgemalt ametialaseid teadmisi (väite 52 faktorskoor -1). Keeleoskuse negatiivse hindamise taga võisid olla ka hirmud seoses eestikeelse aineõpetusega (väite 20 faktorskoor -4 ) ning kahtlused ainealase sõnavara vajalikkuses pärast kooli (väite 29 faktorskoor o; näide 14). Selliselt on keeleoskuse argumentatsioonide fookus selles diskursuses eelkõige integratiivsetel aspektidel. Viimast kinnitab ka asjaolu, et instrumentaalset ainealast sõnavara ning asukohamaast tuleva keeleõppimise kohustust puudutavate väidete osas puudusid selle diskursuse liikmetel selged seisukohad (väidete 1, 6 faktorskoor 0 ).

(14) [29] Ei, geograafiline sõnavara, mida ma sellega veterinaarias, vabandage väga? (Tartu)

Ka sellel diskursusel oli kahe teise diskursusega kattuvaid eristavaid väiteid. Sarnaselt diskursusega "keeleliste valikuvõimaluste tähtsustamise" (kuid veelgi tugevamalt) väljendati vastuseisu eestikeelse aineõppe üldkohustuslikkusele (nõustumine väitega 44, faktorskoor 4). Sarnaselt diskursusega "rahulolu oma keeleoskuse ja integreeritusega" nõustuti (küll mõnevõrra nõrgemalt) oma riigikeele oskuse ja ühiskondliku integreerituse seosega (väite 55 faktorskoor 2). Kokkuvõtteks võib öelda, et seda diskursust defineerivad vilistlased tähtsustasid suuremat paindlikkust nii keelepoliitikas üldiselt (keeleoskuse nõude üleüldisuse kahtluse alla seadmine) kui ka riigikeelsele aineõppele ülemineku osas (suuremate valikuvõimaluste soovimine koolidele ja õpilastele). Kuigi põhimõtteliselt nõustuti integratsiooni kui sellisega, kaheldi riigikeelsele aineõppele ülemineku praeguse korralduse sobivuses.

\subsection{Keeleline ja kultuuriline suletus}

Viimane analüüsis eristuv diskursus on arvuliselt väikseim, sisaldades ühte uuritavat Tallinnast ja ühte Ida-Virust. Kuigi kvantitatiivselt oli Ida-Viru intervjueeritav selle diskursusega seotud negatiivselt (vt tabel 1), erinesid nende kommentaarides ilmnevad seisukohad üksnes osaliselt. Vaatamata seda diskursust defineerivate indiviidide vähesele hulgale on statistiliselt eristuvate väidete hulk üks suuremaid. 
Tabel 5. Diskursust "keeleline ja kultuuriline suletus" eristavad väited

\begin{tabular}{|c|c|c|}
\hline Väite nr & Väide & Faktorskoor \\
\hline 38 & $\begin{array}{l}\text { Alguses ma tahtsin õppida aineid eesti (läti) keeles koolis, aga pärast } \\
\text { pettusin }\end{array}$ & 5 \\
\hline 6 & $\begin{array}{l}\text { Eestikeelse (lätikeelse) ainete õppimise tagajärjel minu aineteadmised } \\
\text { kannatasid }\end{array}$ & 4 \\
\hline 37 & $\begin{array}{l}\text { Eesti (läti) keele sildi all pööratakse vene lapsi eesti (läti) usku - vene } \\
\text { mentaliteedi asemel sunnitakse neile peale eesti (läti) oma }\end{array}$ & 4 \\
\hline 3 & Paljudel ei lähe eesti (läti) keelt pärast kooli enam tarvis & 4 \\
\hline 29 & $\begin{array}{l}\text { Igapäevaelus ei ole mul läinud tarvis seda sõnavara, mille omandasin } \\
\text { koolis, õppides aineid eesti (läti) keeles }\end{array}$ & 3 \\
\hline 40 & $\begin{array}{l}\text { Üleminek eestikeelsele (lätikeelsele) õppekeelele lähtus nii koolide kui ka riigi } \\
\text { poolt peamiselt majanduslikest põhjustest }\end{array}$ & 3 \\
\hline 26 & $\begin{array}{l}\text { Koolis ma kartsin eestikeelset (lätikeelset) aineõpet, ja minu hirm osutus } \\
\text { põhjendatuks }\end{array}$ & 2 \\
\hline 34 & $\begin{array}{l}\text { Tahaksin õppida erinevaid keeli, kuid mitte eesti (läti) keelt. Eesti (läti) keele } \\
\text { suhtes tunnen antipaatiat }\end{array}$ & 0 \\
\hline 27 & $\begin{array}{l}\text { Mul ei ole erilisi eeldusi keelte omandamiseks, seetõttu läheb mul ka eesti } \\
\text { (läti) keele õppimine raskustega }\end{array}$ & -1 \\
\hline 43 & $\begin{array}{l}\text { Pean ennast kultuuriliselt avatuks ja sallivaks inimeseks, st minu jaoks ei } \\
\text { kujuta erinevast rahvusest inimestega suhtlemine erilist raskust }\end{array}$ & -2 \\
\hline 15 & $\begin{array}{l}\text { Oskan veel mõnda keelt (näiteks inglise keelt) piisaval tasemel, et kasutada } \\
\text { seda igapäevaelus }\end{array}$ & -3 \\
\hline 32 & $\begin{array}{l}\text { Eesti (läti) keele õppimine andis mulle võimaluse kokkupuuteks eesti (läti) } \\
\text { kultuuriga. Iga haritud inimene peab teadma selle riigi kultuuri, kus ta elab }\end{array}$ & -3 \\
\hline 7 & $\begin{array}{l}\text { Eesti (läti) keele õppimisel aitas mind väga eesti (läti) meedia kasutamine } \\
\text { ning võimalus kasutada eesti (läti) keelt erinevates olmesituatsioonides }\end{array}$ & -4 \\
\hline 53 & $\begin{array}{l}\text { Eesti (läti) keele omandamise seisukohalt, eestikeelne (lätikeelne) aineõpe } \\
\text { täiendas keeletunde }\end{array}$ & -4 \\
\hline 21 & $\begin{array}{l}\text { Olen valmis suhtlema nii vene kui ka eesti (läti) keeles, ning minu sõprade ja } \\
\text { tuttavate hulgas on nii venelased kui eestlased (lätlased) }\end{array}$ & -5 \\
\hline 63 & $\begin{array}{l}\text { Tänu sellele, et valdan nii vene kui ka eesti (läti) keelt, on mul rohkem } \\
\text { võimalusi saavutada edu kui nendel minu eakaaslastel (eestlastel (lätlastel) } \\
\text { või venelastel), kes valdavad ainult üht keelt }\end{array}$ & -5 \\
\hline
\end{tabular}

Peamise erinevusena võrreldes teiste diskursustega seostub eestikeelsele õppele ülemineku vastasus siin teatud isikliku ilmajäetustundega. Negatiivseid hinnanguid seoses riigikeelse õppega põhjendati nii isikliku pettumuse (nõustumine väitega 38) kui ka konkreetsete aine- ja keelealaste teadmiste saamatajäämisega (nõustumine väitega 6, väite 53 eitamine; näited 14 ja 15).

(14) [6] Jah, nii oli. Sest alguses ma ei saanud millestki aru. --- st ei saanud täielikult aru. Lihtsalt raske oli süveneda nendesse eestikeelsetesse sõnadesse. (Narva)

(15) [6] Seesama kunstiõpetus - meile anti mingid küsimused, me tõlkisime need ära, siis panime kokku vastused ja tõlkisime jälle, nii et mis teadmised seal. Me panime suurema rõhu keelele ja, otse öeldes, kirjutasime kõik õpikust maha. Selle tulemusena kannatasid minu aineteadmised. (Tallinn) 
Ühtlasi olid need vilistlased kriitilised omandatud keeleoskuse ja erialase sõnavara hilisemate rakendusvõimaluste suhtes (väite 29 faktorskoor 3). Lisaks kooliga seotud isiklikele kogemustele on nende kahe noore keelelis-kultuuriline suletus selgitatav ka eestikeelsele õppele ülemineku eesmärkide üldise tajumisega - nad leidsid, et õppekeelevahetus ei arvesta õpilaste keelelis-kultuurilise mentaliteediga (nõustumine väitega 37) ning üleminek põhineb pigem formaalsetel ja majanduslikel kaalutlustel (nõustumine väitega 40).

Teiseks selle diskursuse eristajaks on suhteliselt tagasihoidlik individuaalne keelelis-kultuuriline avatus. Väiteid vabas vormis kommenteerides pidasid vilistlased üldiselt (normatiivselt) kultuurilist avatust ja sallivust oluliseks, kuid personaalset kogemust selgitades eelistati ühekeelseid ja-kultuurilisi valikuid (näide 16; mittenõustumine väidetega 21, 43). Vähese keelelis-kultuurilise avatuse taga näib antud juhul olevat nii isiklike keeleliste ressursside piiratus (väide 15) kui ka teatud hirm võõrkeelse suhtluse ees (näide 16). Hirmu teises keeles rääkimise ees väljendati vaatamata eri keeltes rääkimise varasemale kogemusele. Samas nõustuti keeleõppimise võimalusega keelekeskkonda sattudes, vaatamata algselt tajutud ebakindlusele.

(16) [21] Ei, ma pigem eelistan suhelda vene keeles kui eesti keeles, sellepärast ei nõustu. Vististi hirm - samamoodi nagu mul oli ka inglise keelega. Küllap ei ole keel mulle väga tuttav. Näiteks ma käisin Rootsis tööl, ja seal tuli mul suhelda inglise keeles, kuigi siin ma seda keelt ei rääkinud. Selle tulemusena hakkasin suhtlema. Kui praegu satuksin keskkonda, kus vene keeles ei räägita, hakkaksin samamoodi rääkima. (Narva)

Lisaks vahetute teiskeelsete kontaktide vähesusele iseloomustavad seda diskursust ka suhteliselt piiratud teiskeelsed meediakontaktid (mittenõustumine väitega 7). Individuaalse suletuse ja eestikeelses õppes pettumuse taga võis olla ka isiklikest pragmaatilistest põhjendustest tulenev eripärane olukorrataju (nt ühel juhul ebaõnnestumine eestikeelsetes õpingutes ning eesseisnud Venemaale-kolimine ning teisel juhul kogemus tööintervjuul, kus oli ilmnenud keeleoskuste eelistamine muudele pädevustele).

Lisaks eelkirjeldatud väidetele on sellel diskursusel teiste diskursustega sarnasel määral statistiliselt eristuvaid väiteid, mille nõusoleku suund oli aga erinev. Näiteks erinevalt diskursusest "vastuseis homogeniseerumisele" nõustuti tugevamalt väidetega, mis puudutavad negatiivset kogemust eestikeelse õppega (väited 6, 26, 29). Võrreldes diskursusega "rahulolu oma keeleoskuse ja integreeritusega", kus ohtu kultuurilisele identiteedile ei tajutud, nõustusid selle diskursuse liikmed väitega 37. Kui "keeleliste valikuvõimaluste tähtsustamise" diskursuses peeti igapäevaseid vahetuid ja vahendatud (meedia)kontakte keeleõppimist toetavaks (väide 7), siis antud diskursuses sellega ei nõustutud. 


\section{Kokkuvõte ja arutelu}

Käesolev artikkel keskendus riigikeelse õppega seotud positsioonide selgitamisele venekeelsete gümnaasiumite vilistlaste hulgas. Analüüsis eristus neli riigikeelsele õppele üleminekut iseloomustavat diskursust: "keeleliste valikuvõimaluste tähtsustamine", "rahulolu oma keeleoskuse ja integreeritusega", "vastuseis homogeniseerimisele" ning "keeleline ja kultuuriline suletus".

Artiklis kasutatud Q-metodoloogia võimaldas analüüsida vilistlaste sotsiolingvistilise konteksti erinevate aspektide rolli subjektiivsete positsioonide kujunemisel. Analüüs toetab varasemate uuringute tulemusi (Masso, Soll 2013), mille kohaselt traditsioonilise kvantitatiivse lähenemise ohuks võib olla kontekstuaalsete tegurite alahindamine riigikeelsele õppele ülemineku valmisoleku hindamisel. Käesolevas analüüsis ilmnes kolme diskursuse ühisjoonena ("rahuolu oma integreeritusega", "vastuseis homogeniseerimisele", "keeleliste valikuvõimaluste tähtsustamine") fokuseerumine riiklikke integratsioonipõhimõtteid ja keelepoliitika ühiskondlikke väljundeid puudutavatele argumentidele. Seevastu "keelelise ja kultuurilise suletuse" diskursus keskendus kooli ja indiviidiga seotud väidetele. Analüüsist ilmnes, et igapäevane sotsiolingvistiline keskkond võib soosida teatud orientatsioone- näiteks kakskeelse olmekeskkonnaga harjunud Tallinna ning Ida-Virumaa valdavalt venekeelses keskkonnas üleskasvanud vilistlastele olid olulised keelelised valikuvõimalused. Samuti kaldusid Läti vilistlased väljendama rahulolu oma keeleoskuse ja integreeritusega. Siiski ei pruugi sotsiolingvistiline keskkond ning individuaalsed valikud olla alati üheses seoses - rahulolu enda Eesti ühiskonda integreeritusega väljendasid erineva sotsiolingvistilise kogemusega noored, käesolevas analüüsis nt Tartu ja Ida-Virumaa päritoluga vene õppekeelega gümnaasiumite vilistlased. Avalikkuses suhteliselt homogeense sotsiolingvistilise kontekstina konstrueeritud Ida-Virumaalt pärit vilistlaste positsioonid seoses riigikeelsele õppele üleminekuga jaotusid eri diskursuste vahel kõige mitmekesisemalt.

Analüüs näitas Q-metodoloogilise diskursusanalüüsi mitmekesiseid võimalusi peamiselt kvalitatiivse diskursusanalüüsi kontekstis. Artikli uurimisobjekti - sotsiolingvistiliselt kompleksse teema ehk riigikeelsele õppele ülemineku - puhul seisnes Q-metodoloogilise uurimuse eelis eelkõige selle holistlikus lähenemises (vt nt Watts, Stenner 2012). Puht kvantitatiivses analüüsis võivad indiviidide arvu poolest vähe esindatud, kuid tähenduslikult eristuvad individuaalsete positsioonide mustrid (nt "keeleline ja kultuuriline suletus") jääda tähelepanuta. Q-metodoloogia kvalitatiivne komponent ehk konstrueeritud 63 väitele spontaanselt lisatud kommentaaride analüüs võimaldas iga indiviidi subjektiivseid tõlgendusi tähenduslikult täpsustada. Üksikute väidete ja nende seoste, aga ka indiviidide sotsiolingvistiliste kogemuste vaatlemine (nii eraldiseisvalt kui ka seostatuna) võimaldas analüüsida eestikeelsele õppele üleminekuga seotud individuaalseid positsioone, keskendudes nii üksikutele detailidele kui ka tervikule. 


\section{Viidatud kirjandus}

Aalto, Pami 2003. Constructing Post-Soviet Geopolitics in Estonia. Routledge Studies in Geopolitics. London, New York: Routledge.

Bailey, Kenneth D. 1994. Typologies and Taxonomies: An Introduction to Classification Techniques. Quantitative Applications in the Social Sciences 102. Thousand Oaks: Sage Publications.

Barchak, Leonard J.; Marshall, Russell (Gene) 1998/1999. What do they know of English, who only English know? Ascertaining attitudes toward foreign language study using Q methodology in a public relations framework. - Operant Subjectivity, 22 (1/2), 31-48.

Brown, Steven R. 1980. Political Subjectivity: Applications of Q Methodology in Political Science. New Haven: Yale University Press.

Burt, Cyril 1937. Correlations between persons. - British Journal of Psychology, 28 (1), 59-96. http://dx.doi.org/10.1111/j.2044-8295.1937.tboo862.x

Cattell, Raymond 1973. Personality and Mood by Questionnaire. San Francisco: Jossey-Bass.

Child, Dennis 2006. The Essentials of Factor Analysis. 3rd ed. London, New York: Continuum.

Chouliaraki, Lilie; Fairclough, Norman 1999. Discourse in Late Modernity: Rethinking Critical Discourse Analysis. Edinburgh: Edinburgh University Press. Fairclough, Norman 2003. Analysing Discourse: Textual Analysis for Social Research. London: Routledge.

Dryzek, John S. 2004 [1990]. Discursive Democracy: Politics, Policy, and Political Science. Cambridge: Cambridge University Press.

Grosswiler, Paul 1994. The convergence of William Stephenson's and Marshall McLuhan's communication theories. - Operant Subjectivity, 17 (3/4), 2-16.

Hill, Thomas; Lewicki, Pawel 2006. Statistics: Methods and Applications: A Comprehensive Reference for Science, Industry, and Data Mining. Tulsa: StatSoft.

Housen, Alex 2002. Contextual, output and operational variables in bilingual education in Latvia. - Intercultural Education, 13 (4), 391-408. http://dx.doi.org/10.1080/1467 598022000023849

KKK 2012 = Korduma kippuvad küsimused. Haridus- ja Teadusministeerium. http://www. hm.ee/index.php?047810 (12.12.2012).

Masso, Anu 2010. Geographical perspective on identity construction: Identification strategies of Russian youth in Estonia. - International Journal of Interdisciplinary Social Sciences, 5 (6), 51-62.

Masso, Anu; Kello, Katrin 2010. 2009. a kevadel vene õppekeelega gümnaasiumite õpetajate ja 11. klassi õpilaste seas läbi viidud küsitluse aruanne. - Uurimisprojekti "Vene õpilane venekeelse üldhariduskooli eestikeelses õppes" aruanne. Tartu: Tartu Ülikool.

Masso, Anu; Kello, Katrin 2012. 2011. a läbiviidud ekspertküsitluse aruanne. - Uurimisprojekti "Vene õpilane venekeelse üldhariduskooli eestikeelses õppes" aruanne. Tartu: Tartu Ülikool.

Masso, Anu; Soll, Maie 2013. The transition to Estonian as the language of instruction in upper secondary schools: Readiness of pupils and teachers in Estonia. - Journal of Baltic Studies, avaldamiseks vastu võetud käsikiri.

McKeown, Bruce; Thomas, Dan 1988. Q Methodology. Newbury Park: Sage Publications.

Rannut, Ülle 2005. Keelekeskkonna mõju vene õpilaste eesti keele omandamisele ja integratsioonile Eestis. Tallinn: TLÜ Kirjastus.

Siiner, Maarja 2006. Planning language practice: A sociolinguistic analysis of language policy in post-communist Estonia. - Language Policy, 5 (2), 161-186. http://dx.doi. org/10.1007/s10993-006-9004-9

Singer, Jane B. 1998/1999. Pairing Q methodology and case studies to explore journalists' attitudes toward new media forms. - Operant Subjectivity, 22 (1/2), 1-19. 
Snelling, Susan J. 1999. Women's perspectives on feminism: A Q-methodological study. - Psychology of Women Quarterly, 23 (2), 247-266. http://dx.doi. org/10.1111/j.1471-6402.1999.tbo0357.X

Spearman, Charles 1927. The Abilities of Man: Their Nature and Measurement. New York: Macmillan.

Stephenson, William 1936. The foundations of psychometry: Four factor systems. - Psychometrika, 1 (3), 195-209. http://dx.doi.org/10.1007/BFo2288366

Stephenson, William 1953. The Study of Behavior: Q-technique and its Methodology. Chicago: University of Chicago Press.

Trost, Jan 1986. Statistically nonrepresentative stratified sampling: A sampling technique for qualitative studies. - Qualitative Sociology, 9 (1), 54-57. http://dx.doi.org/10.1007/ BFoog88249

RT 2007, 61, 392 = Vabariigi Valitsuse 25. jaanuari 2002. a määruse nr 56 "Põhikooli ja gümnaasiumi riiklik õppekava” muutmine. Vastu võetud 23.11.2007 nr 235. Riigi Teataja I 2007, 61, 392.

van Dijk, Teun A. 1985. Ideoloogia: multidistsiplinaarne käsitlus. Tartu: Tartu Ülikooli Kirjastus.

Watts, Simon; Stenner, Paul 2012. Doing Q Methodological Research. Theory, Method and Interpretation. Los Angeles: Sage.

Wodak, Ruth 1996. Disorders of Discourse. London: Longman.

Anu Masso (Tartu Ülikool) on uurinud personaalseid kultuurilisi distantse, geo-kultuurilist mobiilsust ja keelelist kommunikatsiooni.

Anu.Masso@ut.ee

Katrin Kello (Tartu Ülikool) on tegelenud vene õppekeelega gümnaasiumite eestikeelsele aineõppele ülemineku küsimustega uurimisprojekti “Vene laps venekeelse üldhariduskooli eestikeelses õppes” (2008-2011) raames.

Katrin.Kello@ut.ee

Valeria Jakobson (Tartu Ülikool) on uurinud rahvusvähemuste meediat, selle rolli kollektiivsete identiteetide ja rahvuslike tähtpäevade kujunemisel ning rahvusvähemuste meedia jälgimise harjumusi.

valeriajakobson@hotmail.com 


\title{
TRANSITION TO STATE-LANGUAGE INSTRUCTION IN UPPER SECONDARY SCHOOLS ACCORDING TO ALUMNI: Q-METHODOLOGICAL DISCOURSE ANALYSIS OF INDIVIDUAL POSITIONS
}

\author{
Anu Masso, Katrin Kello, Valeria Jakobson \\ University of Tartu
}

This article deals with discourses related to the transition to Estonian as the language of instruction in the currently Russian-medium upper secondary schools, based on Q-methodological semi-formalised interviews with alumni (42) of Russianmedium schools in three Estonian regions and, for a comparison, in Latvia. Since Q-methodology combines qualitative and quantitative approaches it enabled the authors to conceive subjective meanings as well as patterns therein (discourses) as they relate to this complex topic. The analysis distinguished four discourses based on the interviewees' agreement with the 63 statements that they were asked to sort (evaluate) and on which they were asked to comment selectively.

The most represented discourse (21 individuals representing all the four regions) was 'valuing the availability of linguistic alternatives'. This title refers to the position that two state languages would eliminate problems rather than create them; agreeing that English was instrumentally more advantageous than Estonian; and valuing the students' right to choose their language of instruction. Somewhat similar was the 'resistance to homogenisation' discourse, represented by four individuals from Estonia, although within this discourse, the critique focused more on instruction (in Estonian) itself (e.g., as detrimental to the student motivation). However, the general necessity for the Russian-speaking population to learn Estonian was also doubted.

The 'linguistic and cultural distanciation' discourse (two representatives from Estonia) additionally expressed personal pessimism both regarding the state policies and as related to personal mono-linguistic and mono-cultural preferences. Opposed to the previous was the 'satisfaction with one's language proficiency and own integration' discourse, represented by the second largest number of individuals (13), six of whom were from Latvia. This pattern of positions expressed personal optimism as well as agreement with official arguments on the benefits of state language skills and a change of instruction language.

Keywords: language politics, education politics, interethnic relationships, transition to state language instruction, Q-methodology, discourse analysis, Russian language, Estonian language, Latvian language 